\title{
Corrigendum
}

\section{Overlooked Thinkers: Stretching the Boundaries of Business Ethics Scholarship (Guest Editors' Introduction) - Corrigendum}

Andrew Wicks, Lindsay Thompson, Patricia Werhane, Norman Bowie

DOI: https://doi.org/10.1017/beq.2021.22, Published by Cambridge University Press, 24 September 2021.

The introduction to the special issue (Wicks et al. 2021, 495) misstated the title of 1 the contribution by Helen Mussell (2021). The correct title of Mussell's article is "The Silenced and Unsought Beneficiary: Investigating Epistemic Injustice in the Fiduciary." The title is correct elsewhere in the issue.

The editors apologize for the error.

\section{REFERENCES}

Mussell, Helen. 2021 "The Silenced and Unsought Beneficiary: Investigating Epistemic Injustice in the Fiduciary." Business Ethics Quarterly 31 (4): 549-71.

Wicks, Andrew, Linsday Thompson, Patricia Werhane, and Norman Bowie. 2021. "Overlooked Thinkers: Stretching the Boundaries of Business Ethics Scholarship." Business Ethics Quarterly 31 (4): 489-99. 